\title{
MAQASHID SYARIAH APPROACH ON THE PMD IN PT BTPN SYARIAH RANTAU PRAPAT NORT SUMATERA
}

\author{
Laila Afni Rambe \\ Sekolah Tinggi Agama Islam Rokan \\ E-mail: lailaafnirambe20@gmail.com
}

\begin{abstract}
Abstrak
1 (satu) tahun Indonesia menghadapi Covid-19 memberikan dampak yang begitu signifikan pada sektor ekonomi. Keadaan Covid-19 yang belum terselesaikan hingga saat ini memperparah kondisi ketidakmerataan ekonomi yang dialami oleh masyarakat Rantau Prapat. Kesulitan ekonomi yang dirasakan masyarakat mendorong PT BTPN Syariah mengeluarkan kebijakan dalam bentuk fitur pembiayaan bagi ibu rumah tangga tanpa adanya agunan. Pembiayaan yang ditawarkan oleh PT BTPN Syariah dinamai dengan PMD. Program PMD merupakan pembiayaan bantuan modal usaha yang perlu untuk dikaji lebih jauh dalam konsep Maqāsșid al-syarī'ah Jaser Auda. Hal ini penting dilakukan mengingat bahwa program PMD berbeda dari program pembiayaan lainnya yang mengharuskan adanya agunan. Selain itu, program PMD juga diinisiasi oleh lembaga keuangan yang berbasis syariah sehingga perlu untuk diketahui apakah program yang ditawarkan sesuai dengan tujuan syariah atau tidak. Penelitian ini termasuk pada penelitian lapangan (field research) dengan menggunakan pendekatan filosofis-empiris. Adapun metode pengumpulan data yang digunakan yaitu wawancara dan observasi. Hasil penelitian menunjukkan bahwa program PMD yang ditawarkan oleh PT BTPN Syariah sesuai dengan konsep Maqāṣid al-syarī'ah Jaser Auda. Dengan demikian dapat diketahui bahwa tujuan syariah tercapai.
\end{abstract}

\section{Kata kunci: PMD; Maqāṣsid al-syar̄̄aah; Jaser Auda; Hukum Islam}

\section{PENDAHUAN}

Kondisi ekonomi nasional semakin memprihatikan setelah 1 (satu) tahun Covid-19 masih melanda Indonesia. Kesulitan ekonomi dirasakan oleh setiap lapisan masyarakat, mulai dari kalangan masyarakat biasa hingga sampai pada sejumlah pengusaha. Kehadiran Covid-19 memberikan tamparan sekaligus evaluasi bagi perekonomian Indonesia, sulitnya mendapatkan pekerjaan juga menjadi salah satu masalah yang dihadapi oleh masyarakat dewasa ini (Rambe, 2020).

Bagi seorang pengusaha bahkan untuk mencapai titik stabil pengeluaran dan pemasukan menjadi kesulitan tersendiri yang dihadapi. Betapa tidak, usaha yang dijalankan tetap harus berjalan disamping tingginya modal yang harus dipenuhi. Selain itu biaya pengembangan usaha juga akan tetap berjalan apabila usaha yang dijalankan ingin tetap bertahan.

Memperhatikan keadaan yang dialami masyarakat saat ini Bank Tabungan menawarkan produk pembiayaan melalui program Paket Masa Depan (PMD). Program yang ditawarkan ini dikhusukan kepada ibu rumah tangga yang memiliki usaha, usaha tersebut tidak dibatasi dalam jenis apapun. Usaha tersebut dapat berbentuk warung, grosir sembako, lahan pertania atau usaha lainnya. Pada program ini nasabah yang dalam hal ini adalah ibu rumah tangga akan diberikan modal usaha atau suntikan dana untuk memperlancar usaha yang dijalankan. Jumlah pinjaman yang diberikan oleh PT BTPN Syariah juga bervariasi tergantung pada jumlah pendapatan usaha yang dimiliki. Pada tahap awal pinjaman akan diberikan pada kisaran Rp. 2.000.000- Rp. 3.000 .000 dan 
selanjutnya apabila proses cicilan lancar tanpa kendala maka untuk tahap kedua pinjaman dapat diajukan dengan jumlah yang lebih tinggi yakni Rp. 5.000.000 - Rp. 5.000.000.

Pada pelaksanaannya setiap ibu rumah tangga akan dibentuk dalam sebuah kelompok dengan keanggotaan 10-15 orang perkelompok. Setiap kelompok terdiri dari ketua dan wakil ketua yang bertugas untuk mengatur pembayaran anggota dan mengingatkan anggota untuk setiap jatuh tempo pembayaran. Setiap nasabah diwajibkan untuk menabung sebanyak Rp. 50.000 yang tersimpan dalam tabungannya. Tabungan tersebut diperuntukan untuk membantu anggota lain yang mengalami kecelakaan, sakit atau keadaan lain yang menyebabkan ia tak mampu membayar cicilannya sebab setiap kelompok memegang prinsip saling tolong menolong ketika ada teman sekelompok yang mengalami musibah.

Sebelum menyetujui pengajuan pembiayaan maka setiap calon nasabah akan disaring terlebih dahulu, survey lapangan, cross check usaha dan pelatihan dalam 8 kali pertemuan. Setalah tahapan terpenuhi maka calon nasabah dinyatakan lulus dan berhak mendapat pembiayaan PMD. Namun perlu diketahui bahwa pencarian dana tidak sepenuhnya diberikan full budget namun akan dilakukan pemotongan untuk biaya cicilan tahap awal. Sehingga ketika nasabah mengajukan pembiayaan sebanyak Rp. 3.000.000 maka nantinya yang akan dicairkan oleh BTPN Syariah sebanyak Rp. 2.750.000.

Menjadi sangat menarik ketika PMD ternyata mengandung akad murabah bil wakalah, artinya BTPN Syariah akan memberikan sejumlah uang kepada nasabah melalui akad wakalah untuk digunakan dalam pengembangan usaha nasabah sebagai bentuk akad Murabahah. Namun ketika disinggung dari segi Maqāșid alsyarī'ah tentu perlu dilihat lebih jauh lagi apakah program tersebut memberikan kemashlahatan atau tidak untuk masyarakat luas.

Artikel ini akan membahas secara rinci bagaimana pandangan Maqāṣid alsyarī'ah Jaser Audah dalam melihat Pembiayaan Masa Depan (PMD) sebagai salah satu program BTPN Syariah yang dikhususkan untuk pemberdayaan wanita, kemudian akan dilihat pula bagaimana tinjauan filosofi pada program PMD yang mendorong kesejahteraan masyarakat.

Pada dasarnya penelitian terkait tentang Paket Masa Depan telah dilakukan oleh penulis terdahulu dalam berbagai bentuk karya ilmiah, diantaranya: penelitian yang dilakukan oleh Ainul Ikhsan dalam bentuk artikel dengan fokus penelitian pada efektivitas program pembiayaan PMD. Selain itu terdapat pula penelitian lain yang dilakukan oleh Elfi, dkk dalam bentuk karya ilmiah dengan fokus kajian melihat pengaruh dari PMD terhadap pemberdayaan ekonomi masyarakat dalam peningkatan kesejahteraan masyarakat.

Berdasarkan karya ilmiah terdahulu sebagaimana yang telah penulis paparkan diatas maka dapat diketahui perbedaan mendalam antara penelitian yang dilakukan penulis dengan peneliti sebelumnya, bahwa penulis terfokus mengkaji bagaimana program Paket Masa Depan jika dianalisis menggunakan Maqāṣid al-syarī'ah. Sehingga akan terlihat apakah nantinya PMD sesuai dengan syariah atau tidak berdasarkan pendekatan Maqāṣid alsyarī'ah.

\section{METODE}

Adapun jenis penelitian yang digunakan dalam penelitian ini adalah penelitian lapangan (field research) yang bersifat kualitatif. Penelitian ini termasuk pada kajian ekonomi syariah yang terfokus pada kajian filosofis sehingga pendekatan yang digunakan adalah empiris-filosofis (Arkham, 2021). Data dikumpulkan dengan metode wawancara dan observasi kepada PT BTPN Syariah dan Nasabah sebagai sumber data primer. Dalam mendukung 
data primer, peneliti juga mengumpulkan data dari sumber sekunder berupa karya ilmiah yang ditulis dan penelitian yang dilakukan oleh peneliti terdahulu (Rambe, 2020). Setelah data terkumpul maka sampailah peneliti pada tahap analisis, analisis dilakukan dengan metode deskriptif kualitatif. Hal ini berarti peneliti memaparkan seluruh data secara gamblang seperti apa adanya data di lapangan.

\section{HASIL DAN PEMBAHASAN PMD Sebagai Pemberdayaan Ekonomi Masyarakat}

BTPN Syariah merupakan Bank Umum Syariah di Indonesia yang memiliki tujuan peningkatan perekonomian masyarakt luas melalui setiap layanan yang dijalankan (Rambe, 2021). Setiap program dijalankan berdasarkan prinsip-prinsip syariah serta sesuai dengan hukum positif yang berlaku. BTPN Syariah melalui fungsinya menawarkan pembiayaan kepada masyarakat yaitu khusus pada ibu rumah tangga yang berkeinginan meningkatkan perekonomian keluarga. BTPN Syariah melalui produknya yang bernama Paket Masa Depan (PMD) berupaya memberdayakan ibu rumah tangga yang memiliki keinginan untuk membantu suami dalam mendorong peningkatan penghasilan. Program PMD ditujukan kepada ibu-ibu yang memiliki keinginan untuk mengembangkan usaha tetapi tidak memiliki akses untuk mengajukan pembiayan kepada bank (Mukhson, 2016: $6)$.

Berdasarkan misi dari TUR (Tunas Usaha Rakyat) yakni membantu keluarga prasejahtera sehingga mendapatkan kehidupan yang lebih baik sehingga sejak 8 Oktober 2010 lalu TUR telah meluncurkan salah satu produk pembiayaan Paket Masa Depan (PMD).(Iyen, 2021) PMD termasuk dalam pinjaman senilai Rp. 1.000.000 - Rp. 3.000 .000 yang cicilannya dilakukan setiap 2 minggu dalam kurun waktu 1 tahun. Selanjutnya pada akhir pembayaran nasabah dapat mengajukan pembiayaan dengan jumlah yang lebih besar bahkan $100 \%$ dari pinjaman sebelumnya. PMD

\section{JQIM}

menyediakan pinjaman tanpa jaminan serta tetap memiliki asuransi jiwa tanpa adanya tagihan asuransi dalam setiap pembiayaan (Lubis, 2020).

Kelompok ibu-ibu tersebut dikenal dengan istilah sentra produktif dengan memegang prinsip Berani Berusaha, Disiplin, Kerja Keras dan Saling Bantu (BDKS). Dengan mengedepankan prinsipprinsip tersebut BTPN Syariah secara rutin memberikan pembinaan kepada setiap kelompok sentra produktif yang terdiri dari 10 hingga 15 anggota. Tujuan dari program PMD adalah untuk meningkatkan kompetensi dan keterampilan usaha ibu rumah tangga agar perekonomian keluarga tetap berkembang. Selain itu, tujuan PMD juga untuk modal usaha,baik usaha yang baru dirintis ataupun usaha yang telah terlaksana sesuai dengan prinsip-prinsip syariah. Kemudian dilarang untuk memberikan pembiayaan yang bertentangan dengan prinsip-prinsip dalam bermualat (Ikhsan, 2018).

Berikut syarat untuk dapat mengajukan pembiayaan PMD pada BTPN Syariah :

a. Perorangan, Warga Negara Indonesia (WNI) dan berdomisili di Indonesia.

b. Wanita yang berasal dari kelaurga pra sejahtera yang telah memiliki sebuah usaha atau berencana memiliki usaha.

c. Usia saat pengajuan pembiayaan minimal 18 tahun dan maksimal 60 tahun.

d. Penduduk setempat yang menetap di perkampungan tersebut.

e. Apabila dalam rumah yang ditinggali terdapat lebih dari 1 kepala keluarga maka yang dapat mengajukan pembiayaan hanya 1 kepala keluarga (Yengsi Siregar, 2021).

Adapun tahap awal dalam pelaksanaan program PMD berawal dari adanya sosialisasi dari BTPN Syariah terkait dengan program yang ditawarkan, sosialisasi dilakukan dalam rangka pengenalan program sekaligus mencari anggota sentra produktif yang tertarik serta memenuhi persyaratan yang ditetapkan. 
Pada umumnya sasaran program tertuju kepada setiap ibu rumah tangga yang memiliki kegiatan usaha baik dalam sektor perdagangan, pertanian, perkembunan dan lain sebagainya.

Setelah melalui tahap seleksi maka setiap calon nasabah akan diberikan pembinaan dalam 10 kali pertemuan yang diadakan 3 kali dalam seminggu. Materi yang diberikan bermacam-macam pada setiap pertemuan, materi pembinaan berkisar pada prinsip-prinsip program PMD, tata cara pelaksanaan cicilan, kewajiban dan hak BTPN Syariah juga nasabah. Di pertemuan terakhir dilakukan pencairan dana sesuai dengan pertimbangan BTPN Syariah, sehingga setiap nominal dalam pengajuan dana tidak seluruhnya dikabulkan. Pertimbangan-pertimbangan akan dilakukan BTPN Syariah seperti perkembangan usaha dan pendapatan omset sehingga semakin baik perkembangan usaha maka semakin besar pula jumlah dana yang dapat diterima.

Untuk lebih jelasnya berikut disampaikan prosedur pemberian pembiayaan PMD :

1) Mengadakan pre-marketing. Pada tahap ini tim BTPN Syariah yang ditugasi dalam hal ini MMS akan mengadakan tiga tingkatan pertemuan. Pertama, silaturahmi dengan aparat setempat dengan melakukan pertemuan dengan aparat desa seperti kelompok PKK sekaligus mensosialisasikan PMD. Disamping itu tim MMS juga akan mencari informasi kepada aparat desamengenai calon nasabah yang akan diberikan pembiayaan apabila disetujui. Kedua, tim MMS akan mengunjungi ibu rumah tangga yang telah dijadikan sebagai target market. Tujuan dari kegiatan ini untuk survey lokas sehingga tim mengetahui alamat serta informasi lainnya yang mendukung pemberian pembiayaan PMD. Ketiga, Projection Meeting. Aktivitas ini merupakan bentuk tindak lanjut dari tahap kedua sebelumnya dengan melakukan wawancara kepada calon nasabah PMD terkait motivasi pengajuan program pembiayaan.

2) Survey dan Interview. Pada tahap ini akan digali informasi terkait usaha yang dijalankan calon nasabah serta menganalisa omset yang didapatkan. Informasi tersebut sebagai bahan pertimbangan persetujuan jumlah dana yang akan diberikan pada tahap awal. Interview juga akan dilakukan terhadap tetangga terdekat nasabah untuk mengetahui gambaran karakter calon nasabah sehingga akan memudahkan tim BTPN Syariah untuk bekerjasama.

3) Pelatihan Dasar Keanggotaan (PDK) termasuk pembentukan kelompok, formateur, penetuan lokasi kelompok sentra. Pada tahap ini akan dilakukan dalam beberapa tahap yakni : Pertama, pelatihan calon nasabah yang telah diseleksi serta telah dilakukan survey wawancara akan diberikan pelatihan dasar keanggotaan. PDK merupakan pemberian informasi secara mendetail tentang PMD dan pelatihan mengenai pengelolaan keuangan secara sederhana. Kegiatan ini wajib diikuti oleh seluruh anggota dalam setiap kelompok sentra dengan persentase kehadiran 100\% tanpa perwakilan. Pelatihan ini diadakan selama 5 (lima) hari berturutturut dengan pemberian materi yang berbeda-beda setiap pertemuan. Bagi nasabah lanjutan yang telah pernah menjadi nasabah PMD cukup mengikuti pelatihan 1 hari atau paling lama 3 hari.

Kedua, pembentukan group dan sentra. Group atau kelompok terdiri dari minimal 1 orang dan maksimal 5 orang. Penambahan anggota group dapat dilakukan sewaktu-waktu selama tidak melebihi jumlah maksimal. Namun ibu dan anak atau saudara kandung tidak diperkenankan berada dalam satu group yang sama. Setiap sentra terdiri dari minimal 1 group dan maksimal 5 group yang akan diketuai oleh 1 orang ketua sentra. Pemilihan ketua sentra berada 
pada wewenang penuh seluruh anggota sentra.

Ketiga, penentuan rumah atau lokasi sentra. Lokasi sentra merupakan tempat Pertemuan Rutin Sentra (PRS) yang dapat berupa rumah salah satu nasabah atau tempat lainnya sesuai dengan kesepakatan seluruh anggota sentra.

4) Maintance Nasabah. Maintance adalah pendampingan terhadap nasabah yang meliputi 2 (dua) hal, yaitu : a) Pertemuan Rutin Sentra dilakukan dalam 2 (dua) minggu setelah pencarian dana dilakukan. Pada pertemuan ini akan dilakukan pembayaran cicilan, setoran atau penarikan tabungan. Pertemuan akan dilakukan ditempat yang telah menjadi tempat pertemuan rutin sentra; b) Monitoring Usaha (MU) dan Surprise Visit (SV). Tahap ini menjadi tahap terakhir dengan menggunakan sistem random sampling minimal 4 (empat) orang nasabah dan dilaksanakan maksimal 3 (tiga) bulan sejak pembiayaan disetujui dan diterima (BTPN Syariah, 2021).

BTPN Syariah melalui program PMD mendorong setiap keluarga prasejahtera terkhusus ibu rumah tangga yang berani untuk melangkah maju melalui usaha tanpa harus menjadikan pendapatan suami sebagai pendapatan pokok keluarga. Program PMD ini sudah mulai diperkenalkan sejak tahun 2011. Program PMD terintegrasi dengan program pemberdayaan wanita pada setiap desa, sehingga secara tidak langsung BTPN Syariah bekerjasama dengan pemerintah desa untuk memproduktifkan ibu rumah tangga (Memori, 2020).

Implementasi pembiayaan pada program PMD menghantarkan masyarakat di Rantau Prapat menjadi daerah yang berdaya saing dengan peningkatan ekonomi yang cendrung naik dalam setiap tahunnya. Pembedayaan wanita dalam bidang ekonomi kelompok dan sosial menjadikan setiap ibu rumah tangga menjadi lebih mandiri dan dapat menciptakan keuangan sendiri.

Pencapaian tersebut tentu didukung oleh program PMD yang memberikan pelayanan pembiayaan pada setiap ibu rumah tangga yang tidak memiliki akses pada perbankan. Pemahaman tentang pengelolaan keuangan keluarga juga terus diedukasi oleh BTPN Syariah pada setiap pertemuan yang telah dijadwalkan. Sehingga pada akhirnya setiap anggota sentra produktif dapat meningkatkan taraf ekonomi keluarga.

Program PMD menggunakan akad murabah bil wakalah. Murabahah adalah akad jual beli atas barang tertentu, dimana penjual akan menyebutkan harga kepada pembeli. Dalam akad murabahah penjual akan menjual suatu barang kepada pembeli dengan meminta kelebihan atas harga jual yang sering disebut dengan margin (Efi dan Anriva, 2019). Akad murabahah bil wakalah meliputi pembiayaan, tabungan wadiah, asuransi jiwa serta adanya santunan terhadap nasabah yang mengalami musibah, seperti suami meninggal dunia (BTPN Syariah, 2020).

\section{Maqāsid al-syarī'ah}

Maqāșid al-syarī'ah belakangan ini banyak digunakan oleh pakar sebagai metode pendekatan hukum Islam baru. Abū Ḥamid al-Gazāli sebagai orang yang pertama kali menyinggung metode menemukan maqāṣid al-syarī'ah secara sederhana, dilanjutkan oleh Imam 'Izzuddin Ibn 'Abd as-Salām, kemudian maqāṣid alsyarī'ah terkenal ditangan Imam asySyāțibī dengan paten-paten yang mulai jelas. Muhammad at-Ṭahir ibn 'Āsyūr terhitung mulai mengembangkan maqāṣid al-syarī'ah kearah modern dan ditangan Jaser Auda maqāṣid al-syarī'ah dijadikan pangkal tolak filosofis berfikirnya dengan menggunakan pendekatan sistem sebagai metode berpikir dan pisau analisisnya (Anwar, 2020). Maqāṣid al-syarī'ah dengan teori Jaser Auda menjadikan upaya pembaharuan maqāṣid kearah aplikatif, sehingga bisa mewujudkan solusi-solusi nyata, tidak hanya pada tataran teori. 
Harapannya konteks permasalahan kontemporer dapat diselesaikan dengan teori ini.

Secara garis besar, maqāșid alsyarīah merupakan gabungan dari dua kata yaitu al-maqāṣid dan al-syarī'ah. Adapun jika dirinci ke akar katanya secara etimologi, maqāssid merupakan bentuk jamak dari kata maqșad yang berarti tujuan, maksud, prinsip, sasaran. Kata maqāṣid tersebut berasal dari kata qașada ( $f$ 'il madi) yang berarti menuju sesuatu. Abu Hamid al-Ghazali memaknai maqāṣid sebagai bagian al-mașālih al-mursalah yaitu kemaslahatan yang tidak disebut secara langsung dalam al-Qur'an (Auda, 2019).

\begin{tabular}{cccr}
\multicolumn{2}{c}{ Sedangkan } & syarỉah & secara \\
etimologi & bemakna & jalan & menuju \\
kebahagiaan & dan & keselamatan & (Al-
\end{tabular} Munawwir, 1997). Adapun berdasarkan terminologi menurut Mahmud Syaltut, syari $^{-} a h$ adalah sekumpulan hukum-hukum yang ditetapkan oleh Allah SWT baik melalui al-Qur'an maupun hadis sebagai pedoman yang mengatur hubungan manusia dengan Allah SWT, manusia dengan sesama manusia, serta alam semesta (Syaltūt, 1966).

\section{Maqāṣid al-syarī'ah dalam Pandangan Jaser Auda}

Jasser Auda mendefenisikan maqāssid al-syarī ah sebagai hikmah dibalik adanya hukum Tuhan di dunia, baik dalam bentuk perintah atau larangan. Maqāṣidalsyar $\vec{i} a h$ dalam pandangan Jasser Auda merupakan sekumpulan tujuan ketuhanan dan nilai-nilai moral yang dapat dijadikan sebagai jembatan antara syarī'ah dengan berbagai tantangan isu-isu kontemporer dan bahkan menjadi kunci utama untuk menjawab tantangan tersebut (Audah, 2013). Bagi Jaser Auda, maqāṣid alsyar $\vec{i} a h$ merupakan salah satu media intelektual dan metode masa kini untuk dalam menetapkan suatu hukum. Maqāșid adalah metodologi dalam keilmuan Islam yang menunjukkan nalar dan agenda Islam (Auda, 2019).

Perubahan definisi maqāṣid alsyari $^{-}$ah membuat pergeseran pada dimensi atau sudut pandang serta teknik penetapan hukum. Jaser Auda sebagai salah satu pegiat kajian maqāșid al-syarī'ah kontemporer memasukkan dimensi-dimensi maqāṣid baru untuk dapat mengisi kekurangan pada konsep maqāṣid tradisional. Hal ini disebabkan maqāșid tradisional tidak menjelaskan secara khusus tujuan suatu nas yang membahas topik fikih tertentu. Selain itu maqasid tradisional dinilai lebih bersifat individu sehingga tidak memasukkan nilai-nilai paling umum seperti keadilan dan kebebasan. Hal inilah yang menjadi ciri khas dari maqāșsid kontemporer ala Jaser Auda dengan tiga usulan dimensi perbaikan :

1) Perbaikan jangkaun hukum maqāṣid kontemporer

Dimensi jangkauan hukum dibagi menjadi tiga tingkatan untuk menyempurnakan maqāṣid kontemporer(Jasser Auda, 2019).

a) Maqāṣid Umum (al-Maqāṣid al'Ámmah)

Maqāṣid ini dapat ditelaah pada seluruh bagian hukum Islam, seperti keniscayaan dan kebutuhan ditambah dengan usulan maqāṣid baru seperti keadilan dan kemudahan (Rambe, 2021). Pada tingkat maqāssid umum adanya perubahan pada pengembangan melalui bahasa-bahasa yang lebih mudah dipahami dalam perkembangan zaman. Sebagaimana pembahasaan ulang tentang darūriyyah al-khamsah (hifz al-dīn, hifz al-nasl, hifz al-'aql, hifz al-nafs, hifz al-māl) dengan menambahkan Hak Asasi Manusia (HAM). Ketika seseorang sedang membahas hifz al$m \bar{a} l$,menurut Jaser Auda secara tidak langsung ia juga telah membahas hal lain berkaitan dengan hifz al-dīn, hifz al-nasl, hifz al-'aql, hifz al-nafs. Jaser Auda menilai hal tersebut sebagai 
sebuah hierarki hukum yang saling keterkaitan (interrelated-hierarchy). Hubungan seluruh tingkatan daruriyah menurut Jaser Auda saling memiliki relevansi sehingga tidak bisa dipisahkan. Seluruh tingkatan menjadi representasi atas jangkauan hukum dan jangkauan orang sehingga seluruh tingkatan tidak dapat berdiri sendiri.

2) Maqāṣsid Khusus (al-Maqāṣid alKhāṣsah)

Para ulama pengkaji maqāșid al-syarī'ah era tradisional banyak yang memandang maqāsṣid al-khāṣṣah ini, seperti karya-karya yang membahas tentang maqāṣid shalat, maqāṣid zakat ataupun maqāṣid nikah. Jasser Auda mengusulkan pembagian maqāṣid al-khāșșah dalam disiplin keilmuan Islam menjadi tema-tema besar pada era perkembangan maqāșid al-syarī'ah kontemporer, seperti: maqāṣsid ekonomi Islam (al-maqāṣid aliqtishādiyyah al-islāmiyyah), maqāṣid politik Islam (al-maqāṣid al-siyāsah al-islāmiyyah),maqāṣid pendidikan Islam (Auda, 2007). Maqāṣid bisa saja mengalami perubahan pada tingkatan ini tetapi perubahan tersebut cendrung lambat karenaterdapat penyesuaian dengan kebutuhan dan berbagai pertimbangan prioritas (Abdurrahman, 2019).

3) Maqāṣid Parsial (al-Maqāṣsid alJuz'iyyah)

Tujuan di balik suatu nash atau hukum tertentu terdapat pada maqāṣid ini, seperti maksud mensyaratkan jumlah saksi tertentu dalam sebuah kasus hukum bertujuan mengungkapkan kebenaran. Contoh lain membolehkan orang sakit untuk tidak berpuasa bertujuan meringankan kesulitan (Auda, 2019). Perubahan sangat mungkin terjadi dalam maqāssid parsial ini, bahkan sering kali berubah sesuai kondisi dan

\section{JQIM}

situasi yang berbeda saat penetapan hokum (Abdurrahman, 2019).

Dalam memaknai maqāṣid alsyarī ah Jaser Auda menggunakan metode deduksi langsung dari pernyataan al-Qur'an dan as-Sunnah. Cara kerja metode deduksi dengan memandang dari hal-hal yang besar menuju hal-hal yang kecil. Apalagi pada kasus-kasus yang telah ada penjelasannya dalam al-Qur' an maupun hadis. Jaser Auda memberikan istilah The evolution of maqās pada kondisi sebuah usaha adaptif terhadap kondisi sekitar. Pembahasaan kembali pengembangan jangkauan maqāṣid alsyarī'ah diperlukan terutama pada tingkatan maqāsid al-juz'iyyah atau parsial pada ketetapan tertentu, dengan demikian penerapan maqāṣid al-syarī'ah sebagai standarisasi efektivitas sistem hukum Islam bukan hanya mengukur secara normatif namun juga mengukur kemampuan untuk menyelesaikan masalah terhadap permasalahan yang bersifat kontemporer.

Enam fitur sistem yang ditawarkan oleh Jasser Auda sebagai pendekatan dalam penerapan maqāṣid al-syarī'ah dalam hukum Islam yaitu :

a) dimensi kognisi dari pemikiran keagamaan (cognition)

b) kemenyeluruhan (wholeness)

c) keterbukaan (openess)

d) hierarki berpikir yang saling mempengaruhi (interelated hierarchy)

e) berpikir kegamaan yang melibatkan berbagai dimensi (multi dimentionality)

f) kebermaksudan (purpose fullness).

Keenam fitur di atas saling erat berkaitan dan saling berhubungan antara satu sama lain. Sehingga membentuk keutuhan sistem berpikir dalam menyelesaikan masalah pada tataran parsial atau juz'iyyah. Pendekatan ini memberikan solusi baru yang sebelumnya tidak terpikirkan dalam diskusi hukum Islam dan uṣul al-fiqh. Mengingat efektivitas suatu 
sistem diukur berdasarkan tingkat pencapaian tujuannya, maka efektifitas sistem hukum Islam dinilai berdasarkan tingkat pencapaian maqāṣid al-syarī'ah-

\begin{tabular}{|c|c|c|}
\hline No & $\begin{array}{c}\text { Teori } \\
\text { Maqāssid } \\
\text { Tradisinonal }\end{array}$ & $\begin{array}{l}\text { Teori Maqāssid } \\
\text { Kontemporer }\end{array}$ \\
\hline 1 & $\begin{array}{l}\text { Menjaga } \\
\text { agama (hifz } \\
\text { al-dinn) }\end{array}$ & $\begin{array}{l}\text { Menjaga, melindungi } \\
\text { dan menghormati } \\
\text { kebebasan beragama } \\
\text { atau berkepercayaan }\end{array}$ \\
\hline 2 & $\begin{array}{l}\text { Menjaga } \\
\text { Keturunan } \\
\text { (hifz al- } \\
\text { nasl) }\end{array}$ & $\begin{array}{l}\text { Teori yang berorientasi } \\
\text { kepada perlindungan } \\
\text { keluarga; kepedulian } \\
\text { yang lebih terhadap } \\
\text { institusi keluarga }\end{array}$ \\
\hline 3 & $\begin{array}{l}\text { Menjaga } \\
\text { Akal (hifz } \\
\text { al- 'aql) }\end{array}$ & \begin{tabular}{lr}
\multicolumn{3}{l}{ Melipatgandakan } & pola \\
pikir dan research \\
ilmiah; mengutamakan \\
perjalanan & untuk \\
mencari & ilmu \\
pengetahuan; & menekan \\
pola pikir & yang \\
mendahulukan & \\
kriminalitas & \\
kerumunan & \\
gerombolan; rr & \\
menghindari & upaya- \\
upaya & untuk \\
meremehkan & kerja \\
otak. & \\
\end{tabular} \\
\hline 4 & $\begin{array}{l}\text { Menjaga } \\
\text { kehormatan } \\
; \text { menjaga } \\
\text { jiwa (hifz } \\
\text { al-nafs) }\end{array}$ & $\begin{array}{l}\text { Menjaga dan } \\
\text { melindungi martabat } \\
\text { kemanusiaan; menjaga } \\
\text { dan melindungi hak- } \\
\text { hak asasi manusia }\end{array}$ \\
\hline 5 & $\begin{array}{l}\text { Menjaga } \\
\text { harta } \\
\text { (hifz al- } \\
\text { māl) }\end{array}$ & $\begin{array}{l}\text { Mengutamakan } \\
\text { kepedulian sosial; } \\
\text { menaruh perhatian } \\
\text { pada pembangunan } \\
\text { dan pengembangan } \\
\text { ekonomi; mendorong } \\
\text { kesejahteraan manusia; } \\
\text { menghilangkan jurang } \\
\text { antara miskin dan } \\
\text { kaya. }\end{array}$ \\
\hline
\end{tabular}

nya. Hal ini bermakna sejauh mana tingkat problem solving yang dimilikinya terhadap permasalahan tertentu, apakah lebih efektif, lebih berdaya guna dan lebih membawa manfaat yang besar bagi umat dan kemanusiaan (Abdullah, 2018). Hal ini bisa diwujudkan pada tataran maqāṣid aljuz'iyyah. Reformasi hukum Islam kontemporer yang digagasi oleh Jaser Auda dengan fitur melihat tujuan (maqāssid) yang hendak dicapai dalam metodologi penetapan hukum Islam.

Hal ini berbeda jika dibandingkan dengan jangkauan hukum maqāṣid tradisional pada masa Imam asy-Syātibī, beliau mengklasifikasikan maqāṣid alsyar $\bar{l}^{\circ} a h$ menjadi tiga tingkatan yakni : darūriyyah (primer), hājiyyah (sekunder), tahsiniyyah (tersier)(Al 'Abidhi, 1992). Beliau juga menerapkan tingkatan hirarki yang saling mengeliminasi, dimana tingkatan tertinggi merupakan darūriyyah (primer) ketika sudah terpenuhi hal tersebut dapat mengliminasi hājiyyah (sekunder) yang diletakkan di bawahnya, begitu juga untuk tahsiniyyah (tersier). Sebuah teori maqāșid al-syarī ah untuk mencapai tujuan suatu perkara dapat dipahami dengan mencari asbabun nuzul, illat hukum, memahami bahasa Arab yang baik ('Ala Arkham, 2020) Pandangan ini menjadikan pernyataan perintah dan larangan tegas melalui ilat dari perintah dan larangan.

Jaser Auda memetakan konsep maqāsid kontemporer dengan pergeseran paradigma (shiftting-paradigm). Pergeseran tersebut terletak pada pandangan maqāṣid tradisional yang mengedepankan protection (perlindungan) dan preservation (penjagaan, pelestarian). Sedangkan teori maqāṣid kontemporer lebih menekankan development (pembangunan, pengembangan) dan human right (hak-hak manusia) (Jasser Auda, 2019). Pergeseran paradigma dari maqasid tradisionaisme menuju maqasid kontemporer dapat digambarkan sebagaimana berikut : (Husein, 2018).

Tabel 1. Pergeseran Paradigma Maqāṣsid 
Pergeseran cakupan dan sasaran ini kemudian menjadikan maqāṣid kontemporer lebih luas. Tujuan dari hukum Islam (maqāṣidal-syarī'ah al-Islāmiyyah) menjadi prinsip fundamental yang sangat pokok dan sekaligus menjadi metodologi dalam keyakinan Jaser Auda. Adanya jangkauan maqāṣid lebih luas, membuat efektifitas dari sebuah sistem dapat diukur berdasarkan terpenuhinya tujuan yang hendak dicapai. Efektifitas dari sistem hukum Islam juga diukur berdasarkan terpenuhinya tujuan pokok.

Human Development Index (HDI) dan Human Development Targets (HDT) ditawarkan Jaser Auda untuk merealisasikan tujuan pokok dari kemaslahatan yang ingin dicapai dalam maqāṣid (Jasser Auda, 2007). HDI dan HDT bisa diuji, dikontrol, diukur, dan divalidasi dari waktu ke waktu. Standarisasi terhadap suatu tujuan yang bisa divalidasi dari waktu ke waktu membuat tujuan yang ada menjadi lebih jelas, terarah dan dapat dirasakan sejauh mana problem solvingnya.

\section{Metode Penggalian Maqāṣsid Al-Syarī'ah Menurut Jaser Auda}

Meskipun maqāṣid al-syarī'ah sudah sering dikaji sejak era Imam AlGhazzali, Imam Syatibi, Ibnu 'Âsyur, hingga sekarang, namun belum ada metode yang mapan untuk menemukan maqāșid alsyari'ah. Ciri khas metode penggalian maqāṣid al-syarī'ah untuk ulama zaman dahulu berdasarkan metodelogi kembali kepada teks, maksud-maksud digali dari teks dengan pembacaan kebahasaan, asbābun nuzul, 'illat dan lain sebagainya. Adapun untuk pengkaji kontemporer meskipun tidak bisa seragam dalam merumuskan metode identifikasi maqāșid al-syarī'ah, bahkan beberapa pengkaji tidak secara tegas menyatakan metode tersebut. Namun metode induksi (istiqra $\bar{a}^{\prime}$ ) adalah metode yang paling banyak diakui dan disebutkan oleh pengkaji kontemporer (Anwar, 2020).

Metode induksi diakui pengkaji karena maqūṣsid al-syarī'a sendiri merupakan suatu tujuan yang bersifat umum yang dapat diamati dalam berbagai kasus penetapan ketentuan hukum syariah. Cara kerja metode induksi sendiri adalah berangkat dari kasus-kasus khusus untuk kemudian dirumuskan menuju kesimpulan secara umum.

Penjelasan sederhana dipaparkan Jasser Auda untuk menggali maqāṣid alsyarīah dengan menyatakan bahwa maqāṣid al-syarī'ah adalah cabang ilmu keislaman yang menjawab segenap pertanyaan-pertanyaan yang sulit dan untuk mengetahui hal tersebut dapat diwakili oleh sebuah kata yang tampak sederhana, yaitu "mengapa". Pertanyaan mengapa dibutuhkan untuk menggali kasus-kasus khusus untuk disimpulkan secara umum. Hal ini untuk membuktikan bahwasanya perilaku dalam sebuah kasus ada keterkaitan dengan maqāṣid al-syarī'ah. Sedikit banyak metode tersebut memiliki kesamaan dengan metode induksi (istiqrā').

Maqāṣid al-syarī'ah mampu menjelaskan hikmah di balik aturan syariat Islam dengan menjawab pertanyaanpertanyaan tersebut. Sederhananya, maqāṣid al-syarī'ah adalah sebuah cara guna mencapai alasan tertinggi dalam penetapan dan penerapan hukum Islam. Dalam mewujudkan pemahaman yang utuh mengenai maqāṣid al-syarī'ah maka diperlukan pemahaman posisi tujuan dalam tingkatan "mengapa", karena hal tersebut dapat membentuk sebuah alasan hukum yang terjadi diantara perilaku manusia. Hingga maqāṣid al-syarī'ah menjadi dasar filosofis terhadap adanya sebuah ketetapan hukum.

Secara sederhana tingkatan hukum merupakan sebuah jawaban atas pertanyaan "mengapa". Tingkatan hukum ini dapat dimulai dari tingkatan hukum terendah yaitu tanda-tanda (symbol) yang muncul dalam perilaku manusia, begitu pula dalam sebuah disiplin ilmu. Rincian penjelasan dari setiap tingkatan yang ada dalam gambar tersebut dapat dipahami berdasarkan : 
1) Sign (symbol) merupakan salah satu indikator yang muncul dalam perilaku kehidupan manusia, sebagai contoh lampu merah merupakan tanda harus berhenti dilampu lalu lintas.

2) Hukum adalah ketentuan yang mengatur perilaku manusia.

3) Maslahah adalah tingkat hukum untuk kepentingan bersama, kesamaan kebutuhan yang dikandung dalam suatu produk hukum yang ditetapkan.

4) Moral value yakni tingkat hukum berupa nilai-nilai moral yang berlaku dan terkandung pada maslahat pada suatu produk hukum.

5) Filosofis merupakan hukum mendasar terhadap setiap perilaku manusia. Pada tingkatan inilah maqāsșid berlaku dan menjadi dasar pemikiran utama terbentuknya ekonomi Islam. Maqāșid al-syarī'ah menempati posisi filosofis dan mempengaruhi setiap tingkatan di bawahnya.

6) Iman menjadi hukum tertinggi dalam setiap perilaku manusia, tak terkecuali dalam disiplin ilmu yang dikembangkan dalam perspektif Islam.

Mencari sebuah makna maqāṣid pada tingkatan-tingkatan membawa pada perpindahan makna tersirat menuju makna yang jelas dan dari tingkat perbuatan, menuju tingkat hukum. Dengan demikian kita akan mencapai tujuan dari setiap tingat kemaslahatan dan kemanfaatan. Pada akhirnya sampai pada titik pencapaian prinsip-prinsip dasar dan akidah-akidah pokok, seperti prinsip keadilan dan kerahmatan, serta segenap sifat-sifat Allah SWT (Audah, 2013)

\section{al-Maqāṣid al-'Āmmah dalam Perilaku Ekonomi}

Maqāṣid al-'āmmah adalah tujuan hukum yang dapat dilihat secara keseluruhan dalam setiap bab-bab syarī'ah yang termasuk dalam kulliyāt alkhamsah.Dengan jangkauan subjek yang lebih luas maka makna al-hifdzu (penjagaan) menjadi berkembang. Sifat dari maqūṣid al-'ämmah memiliki karakteristik yang tidak berubah dari waktu ke waktu (Tofiin, 2018) Fokus utama maqāṣid alsyarī'ah dalam perilaku ekonomi Islam ialah menumbuhkan kemanusiaan yang kuat dari sisi faith (keyakinan) maupun kemampuan berfikir (Auda, 2017).

al-Maqāṣid al-Khāṣṣah dalam Hukum Transaksi

Maqāṣid al-khāṣsah merupakan tujuan hukum khusus. Tujuan khusus tersebut diturunkan dari maqāṣid umum untuk mengetahui maksud yang terkandung di dalam maqāșid al- 'āmmah (Tofiin, 2018: 38) Perubahan pada tingkatan maqāṣid dapat berubah dalam sesuai dengan kebutuhan dan pertimbangan prioritas tambahan. Agar tujuan dari maqāṣid alkhāsșah dapat tercapai maka perlu dipahami makna tersirat dari fenomena ekonomi atau sosial yang terjadi. Ketika aktivitas ekonomi tersebut dapat menjaga nilai keadilan dalam harta maka dapat disimpulkan bahwa tujuan maqāșid alkhāsșah terlah tercapai.

Unsur pendukung ketika diterapkan pada penerapan hukum, maka aspek kemaslahatan yang diinginkan dapat berubah dan berkembang menjadi semakin lebih luas sesuai dengan kebutuhan sehingga keadilan bisa tercapai dalam maqāṣid al-khāsșah. Keadilan yang nyata bisa terjadi untuk para pihak bukan hanya sebagai moral value akan tetapi dapat dirasakan secara umum. Akan tetapi tujuan yang hendak dicapai dalam setiap transaksi dengan mewujudkan keempat hal di atas berupa menjaga nilai keadilan dalam harta (hifdzu al-'adālah fìmu'āmalah) akan susah dicapai tanpa menjabarkan maksud dan tujuan pada maqāṣid al-juz'iyyah.

Maqāșid al-syarī'ah merupakan suatu tujuan yang hendak dicapai yakni kemashlahat bagi seluruh manusia. Value kemashlahatan dilihat dari sudut pandang 
Maqāṣid al-syarīah Jaser Auda terletak pada tujuan-tujuan utama yang akan dicapai, meliputi: hifz ad-dīn, hifz an-nafs, hifz al-'aql, hifz an-nasl, hifz al-māl dan hifz al-irdi. Hal ini bermakna bahwa ketika suatu aktivitas ekonomi bertentangan dengan tujuan syariah maka aktivitas tersebut harus dihentikan.

Diketahui perempuan yang pada umumnya berperan sebagai istri tanpa adanya kewajiban bekerja untuk mencari nafkah dalam Islam. Namun pemahaman demikian terkikis dengan banyaknya ibu rumah tangga hari ini yang ikut serta membantu suami dalam bekerja untuk mencukupi kebutuhan keluarga. Kategori pra-sejahtera yang dialami oleh sebahagian besar masyarakat di Rantau Prapat belum mampu mencukupi dan memenuhi kebutuhan pangan maupun sandang keluarga (M Kamal Hadi, 215). Ketimpangan ekonomi menyebabkan distribusi pendapatan tidak sehat menjadi masalah yang kerap kali dialami oleh sebahagian besar keluarga.

Kebijakan paling efektif dan efesien yang mampu mendorong peningkatan ekonomi keluarga adalah dengan mengoptimalkan pembiayaan pada sektor keuangan. Lembaga keuangan diharapkan memberikan dan membuka jalan seluasluasnya kepada masyarakat dan berbagai UMKM untuk dapat mengakses berbagai fitur pembiayaan. Dengan demikian ada upaya yang mampu mendorong pemanfaatan sektor keuangan pada perekonomian keluarga.

Industri perbankan syariah dalam hal ini PT BTPN Syariah bergerak cepat dengan penyediaan layanan PMD yang diperuntukan kepada ibu rumah tangga yang memiliki mimpi untuk meningkatkan perekonomian keluarga. PT BTPN Syariah tidak hanya terfokus dalam penyedian modal usaha namun ikut serta melakukan pendampingan melalui inovasi-inovasi dengan pembinaan model bisnis yang sesuai dengan kebutuhan masyarakat. Pendampingan dilakukan agar kapasitas usaha ibu rumah tangga dapat tumbuh dan berkembang (Ikhsan, 2018).

Fitur pembiayaan PMD oleh PT BTPN Syariah ditawarkan kepada seluruh ibu rumah tangga dengan tujuan untuk memberikan bantuan modal usaha. Upaya yang dilakukan oleh PT BTPN Syariah merupakan bentuk dukungan kepada masyarakat yang memiliki usaha namun tidak memiliki modal yang cukup dalam pengembangan usaha. Pembiayaan PMD ditawarkan dengan mewujudkan impian seluruh masyarakat untuk mendapat kesejahteraan.

Produk pembiayaan sudah sepantasnya memberikan kemashlahatan bagi seluruh manusia. Hal ini merupakan bentuk implementasi dan tujuan dari syariat Islam yang mengharuskan adanya kebermanfaatan bagi seluruh masyarakat. Apabila dihubungkan dengan konsep Maqāșid al-syarī'ah Jaser Auda yang mengharuskan memelihara hifz ad-dīn, hifz an-nafs, hifz al-'aql, hifz an-nasl, hifz al$m \bar{a} l$ dan hifz al-irdi maka program PMD memiliki keselarasan dan berhasil mencapai tujuan dari Maqāșid al-syarì'ah.

Maqāșid al-syarī'ah Jaser Auda yang pada dasarnya tidak memisahkan seluruh tingkatan maqasid, memberikan ruang yang sebesar-besarnya kepada seluruh masyarakat untuk mendapatkan pembiayaan dari lembaga keuangan. Apabila ditinjau lebih jauh lagi bahwa Maqāṣid al-syarīah kontemporer menambahkan Hak Asasi Manusia (HAM) sebagai salah satu hak yang harus dilindungi. Sebagai warga negara Indonesia sudah barang tentu setiap masyarakat memilii kedudukan yang sama di hadapan hukum. Kemudahan mengakses lembaga keuangan yang didapatkan oleh setiap masyarakat juga menjadi bagian dari HAM itu sendiri.

Jaser Auda memposisikan Maqāṣid al-syaríah sebagai bentuk tujuan filosofis yang bersifat fundamental dalam sebuah aktivitas ekonomi. Keberhasilan suatu kegiatan ekonomi dalam mencapai tujuan syariah dilihat dari standarisasi konsep 
Maqāsṣid al-syarī'ah. Dengan kata lain akan dilihat seberapa besar tingkat problem solving yang dilakukan PT BTPN Syariah dalam mengatasi problem ketimpangan sosial atau ketidakmerataan ekonomi masyarakat.

Adanya kebijakan dari PT BTPN Syariah untuk melakukan pelatihan dan pengembangan keahlian dalam mengelola usaha milikinya, tampaknya senada dengan konsep Maqāṣid al-syarī'ah Jaser Auda dalam menjaga akal yakni dengan dilakukannya peningkatan kompetensi SDM, dalam hal ini pelatihan manajerial ibu rumah tangga. Bagi Jaser Auda pembangunan SDM merupakan hal yang penting untuk dilakukan sebab skill yang dimiliki menghantarkan seseorang kepada tujuan hidup yang lebih baik. Konstruksi Maqāṣid al-syarī'ah yang dicanangkan Jaser Auda dilihat dari aspek menjaga harta memiliki relevansi dengan pembiayaan PMD. Hal ini dapat dirujuk dari banyaknya usaha ibu rumah tangga yang survive dengan adanya bantuan modal dari PT BTPN Syariah. Sudah barang tentu seluruh manfaat tersebut juga akan dirasakan dalam menjaga jiwa, keturunan bahkan agama. Sebab tidak dapat dipungkiri bahwa letak problem kesejahteraan berada pada posisi keuangan keluarga.

Fakta tersebut dapat kita lihat dari semakin tinggi tingkat kesejahteraan ekonomi keluarga maka akan terjamin juga kehidupan keturunannya. Ketika kesejahteraan keluarga terjamin maka semakin bertambah pula tingkat ketakwaan keluarga sehingga tercapai tujuan Maqāșid al-syarī'ah yakni menjaga agama. Seluruh pencapaian yang hendak dicapai oleh BTPN Syariah melalui pembiayaan PMD dengan memfokuskan peningkatan peran ibu rumah tangga dalam membantu keluarga untuk meningkatkan kesejahteraan keluarga. Hal ini sesuai dengan konsep Maqāșid al-syarīah yang dibawa oleh Jaser Auda tanpa harus memisahkan seluruh hierarki Maqāṣid al-syarī‘ah.

\section{KESIMPULAN}

Program pembiayaan yang diberikan oleh PT BTPN Syariah kepada seluruh ibu rumah tangga tanpa agunan menjadi salah satu kebijakan dalam rangka peningkatan ekonomi keluarga pada masa pandemi. Fitur pembiayaan yang ditawarkan adalah Program Masa Depan (PMD). Program PMD apabila dilihat dengan kacamata Maqāșid al-syarī'ah Jaser Auda, tampaknya program ini memberikan kemanfaatan yang besar bagi perbaikan kesenjangan ekonomi di tengah-tengah masyarakat. Kebermanfaat yang dirasakan oleh masyarakat menjadi sebuah fakta program PMD telah sesuai dengan tujuan dari syariat Islam yaitu kemashlatan masyarakat umum. Dengan demikian apabila tujuan dari syariat Islam terlaksana dalam PMD maka program tersebut boleh dilakukan dengan mempertimbangkan manfaat yang dirasakan masyarakat umum.

\section{REFERENSI}

Abdurrahman, L. T. (2019). Pendekatan Maqāṣid al-syarī'ah Kontemporer dalam Perilaku Ekonomi. AnNawa:Jurnal Studi Islam, 1(2), 7.

Ainul Ikhsan. (2018). Efektifitas Program Pembiayaan Paket Masa Depan di Btpn Syariah dalam Memberdayakan Perempuan untuk Mengembangkan Ekonomi Keluarga. Maqdis: Jurnal Kajian Ekonomi Islam, 3(1), 2.

Al-Munawwir. (1997). Kamus ArabIndonesia Terlengkap: Ahmad Warson Munawwir. Pustaka Progresif.

Amin Abdullah. (2018). Membumikan Hukum Islam Melalui Maqāșid asySyarī'ah.

BTPN Syariah. (2020). Keuntungan Dalam Program Paket Masa Depan (p. 10).

BTPN Syariah. (2021). Prosedur dalam $P M D$.

Efi Elmi Fitri Siregar, Della Hilia Anriva, (2019). Pengaruh Pembiayaan Paket Masa Depan (PMD) Btpn Syariah terhadap Pemberdayaan Ekonomi Masyarakat Prasejahtera di Kecamatan 
Kampar; Studi Kasus PadaBTPN Syariah Cabang Kampar. Jurnal Islamika, 2(1), 14.

Emi Memori Ritonga. (2020). PMD Program BTPN Syariah.

Hamka Husein Hasibuan. (2018). Pemikiran Maqashid Syariah Jase Audah. Jurnal Academia, 5(1), 18.

Hammadi Al 'Abidhi. (1992). Asyātib̄̄ Wa Maqāsìdu Al-Syarī'ah. Dar Quthibah.

Iyen. (2021). Paket Masa Depan (p. 20).

Jasser Auda. (2007). "Maqāsid al-Syarī'ah as The Philosophy of Islamic Law" di hadapan Majelis Keilmuan Islam Qatar.

(2017). Universitas Negeri Yogyakarta dalam pembekalan rencana pembentukan jurusan Ekonomi Islam di UNY.

(2019). Membumikan Hukum Islam Melalui Maqasid Syariah.

(2013). al-Maqāşsid Untuk

Pemula: diterjemahkan oleh 'Ali Abdul Mon'im. UIN Suka Press.

Lubis, K. (2020). Paket Masa Depan.

Mahmud Syaltūt. (1966). Al Islām: Aqîdah Wa al-Syarī'ah. Dār al- Qalam.

Muhammad Ai Ali Mukhson, M. M. M. dan L. B. H. (2016). Factors Affecting The Decision to Take Credit Customers Future Program Package (PMD) in Bank Btpn Syariah (Case Study at The State Saving Bank Syariah Pamularsih KCS). Journal of Management, 2(2), 3.

M Kamal Hadi, Pelaksanaan Akad Murabahah Pada Pembiayaan Modal Kerja PT. BRI Syariah Cabang Pekanbaru Ditinjau Menurut Ekonomi Islam, Universitas Islam Negeri Sultan Syarif Kasim Riau, 2015

Rambe, Laila Afni. (2020). Islamic Law Review on Use of Go-Pay in Payment of Zakat. Ulul Albab: Jurnal Studi dan Penelitian Hukum Islam 3 (2), 15.

_. (2020) Praktik Martuppak Martahi Di Desa Sibargot Kabupaten Labuhanbatu Sumatera Utara Ditinjau Dari Perspektif Utang Piutang." AlHurriyah 5 (2), 1.
Rambe, Laila Afni dan Muhammad Alwi

Dalimunthe. (2021). Efektivitas

Peraturan Daerah Kota Padang Nomor

21 Tahun 2012 Tentang Pengelolaan

Sampah Di Kelurahan Gurun Laweh

Nan XX Kecamatan Lubuk

Bagaluang." Populika: Kajian Sosial dan Humaniora 6 (1) 3.

Rambe, Laila Afni, Uswatun Khasanah dan

Mohammad Saddam Jamaluddin

Ishaq. (2021) Analisis Pengaruh Spin-

Off Bagi Unit Usaha Syariah Di Indonesia. Muslim Heritage 6 (1), 2.

Sitta 'Ala Arkham. (2020). Maqasid Syariah Dalam Wakaf Saham. AlMaslahah: Jurnal Ilmu Syariah, Vol. 16(2).

https://doi.org/https://doi.org/10.24260 /al-maslahah.v16i2.1752

Syamsul Anwar. (2020). Studi hukum Islam Kontemporer Bagian Dua. UAD Press.

Tofiin. (2018). Putusan Mahkamah Konstitusi Nomor 30-74/PUUXII/2014 Dalam Perspektif Maqāsid Syarī'Ah.

Yengsi Siregar. (2021). Syarat-Syarat PMD BTPN Syariah (p. 5). 